\title{
Body size variation of a high-Arctic seabird: the dovekie (Alle alle)
}

\author{
Katarzyna Wojczulanis-Jakubas - Dariusz Jakubas · Jorg Welcker • \\ Ann M. A. Harding • Nina J. Karnovsky • Dorota Kidawa • Harald Steen • \\ Lech Stempniewicz $\cdot$ Cornelis J. Camphuysen
}

Received: 15 October 2010/Revised: 8 December 2010/Accepted: 9 December 2010/Published online: 30 December 2010

(C) The Author(s) 2010. This article is published with open access at Springerlink.com

\begin{abstract}
Variation in body size among subpopulations of the same species may reflect phenotypic or genetic responses to environmental gradients or geographical distance. Here, we examine geographical variation in the body size of the dovekie (Alle alle), the most numerous highArctic seabird. Locations of dovekie breeding sites are largely restricted to the high-Arctic zone of the Atlantic. We compared wing length, head-bill length, body mass, and a body size index of 1,076 birds from nine main colonies spanning a large part of the breeding range of the species. Results suggest morphological variation across the studied populations of dovekies, with a longitudinal increase in body size from west to east. The smallest birds breed in the western part of the population (Greenland and Jan Mayen), middle-sized individuals on Svalbard, and the
\end{abstract}

K. Wojczulanis-Jakubas $(\bowtie) \cdot$ D. Jakubas · D. Kidawa ·

L. Stempniewicz

Department of Vertebrate Ecology and Zoology,

University of Gdańsk, 80-441 Gdańsk, Poland

e-mail: biokwj@univ.gda.pl

J. Welcker $\cdot$ H. Steen

Norwegian Polar Institute, Polarmiljøsenteret,

9296 Troms $\varnothing$, Norway

A. M. A. Harding

Environmental Science Department, Alaska Pacific University, Anchorage, AK 99508, USA

\section{N. J. Karnovsky}

Department of Biology, Pomona College,

Claremont, CA 91711, USA

C. J. Camphuysen

Department of Marine Ecology, Royal Netherlands Institute for Sea Research, 1790 AB Den Burg, Texel, The Netherlands largest birds (A. a. polaris subspecies) breed in the eastern part of the studied area, Franz Josef Land. Environmental (air temperature, wind speed, and sea surface temperature) and geographical (intercolonial distance) parameters were analyzed to explore potential mechanisms driving differences in body size. The body size of birds increased significantly with decreasing air temperature, but only when the two subspecies were considered. We did not find a relationship between sea surface temperature and body size of birds. Also, no close relationship was revealed between birds' body size and the geographical distance between colonies. Whether the body size variation of dovekie can be explained by phenotypic plasticity in response to environmental conditions in wintering areas or a pattern of distance-independent gene flow between colonies remains to be explored.

Keywords Alle alle Arctic $\cdot$ Body size variation . Dovekie $\cdot$ Morphological variation

\section{Introduction}

Bird species that occur over large geographical areas often show gradual variation in body size across their range, supposedly developed in response to physical and/or biological clines in the environment. A pattern of large individuals prevailing in colder areas is often observed (e.g. James 1970; Ainley 1980; Monaghan et al. 1983; Moen 1991). This pattern has most often been explained by the heat conservation hypothesis, where heat conservation increases via a higher surface area to volume ratio [known as Bergman's rule at the interspecific level (Bergmann 1847) or James's rule for within-species patterns (James 1970; Blackburn et al. 1999)]. For example, a significant 
negative relationship between the size of several bird species and air temperature was recently reported in Ashton's (2002) meta-analysis. Morphological variation within-species may also be explained by the starvation resistance hypothesis, commonly evoked in studies of mammals, that assumes that larger body size enables animals to store larger amounts of body reserves and thus decreases starvation risk (Calder 1974). Alternatively, body size differentiation may also result from patterns of ancestral colonization and subsequent diversification, for instance as in the case of the snow petrel Pagodroma nivea (Jouventin and Viot 1985; Barbraud and Jouventin 1998).

Although morphologic variation has been described for many bird species, relatively little is known about the relationship between body size and environmental parameters. Moreover, the majority of studies have focused on species from temperate zones, with very few from higher latitudes (reviewed by Ashton 2002). More studies of species from different geographical areas are needed to fully understand the mechanisms driving the patterns observed.

In this study, we examined geographical variation in the body size of the dovekie (or little auk, Alle alle) across a large part of its high-Arctic breeding range. The dovekie is the most numerous alcid in the Atlantic Ocean and probably one of the most numerous seabirds of the world $(>37$ million pairs, Kampp et al. 1987; Mehlum and Bakken 1994; Isaken and Bakken 1996; Boertmann and Mosbech 1998; Isaksen and Gavrilo 2000; Stempniewicz 2001; Egevang et al. 2003). The dovekie breeds exclusively in the northern polar zone of the Atlantic, from $60^{\circ} \mathrm{N}$ (south Greenland) to $82^{\circ} \mathrm{N}$ (Franz Josef Land) and from $67^{\circ} \mathrm{W}$ (eastern Baffin Island) to $98^{\circ} \mathrm{E}$ (Severnaya Zemlya), with the largest colonies located between 70 and $80^{\circ} \mathrm{N}$ (Thule District, NW Greenland; Scoresbysund, E Greenland and Spitsbergen; Stempniewicz 2001; Fig. 1).

Two subspecies have been distinguished based on biometric characteristics (Stenhouse 1930), with the smaller, nominative A. a. alle breeding mainly on Svalbard, Greenland and Jan Mayen, and the distinctively larger $A$. $a$. polaris breeding solely on Franz Josef Land, and possibly Severnaya Zemlya (Stempniewicz 2001). Birds with a flattened wing $\geq 130 \mathrm{~mm}$ and culmen length $\geq 17 \mathrm{~mm}$ were considered to be A. a. polaris. However, some reports suggested that there is significant overlap in measurements between the two subspecies but the status of birds from both origins was retained (Vaurie 1965; Cramp 1985; Stempniewicz et al. 1996). Rough comparisons of existing body size data of dovekies breeding in Svalbard (Stempniewicz et al. 1996), Greenland (Roby et al. 1981) and Jan Mayen (Camphuysen 1989) also suggest some differentiation within the nominative subspecies, but a comprehensive analysis of body size data across the geographical range of the species has never been attempted.

Here, we examine morphometric variation in dovekies breeding at nine principal colonies that span much of their longitudinal and their entire latitudinal breeding range. To understand patterns driving geographical differences in body size, we examined the relationship between body size and both environmental (air temperature, wind speed, and

Fig. 1 Distribution and relative size of breeding colonies of dovekies (black circles), and location of sampled colonies (white rectangles with codes of the sites) and sea surface temperatures (empty rectangles)

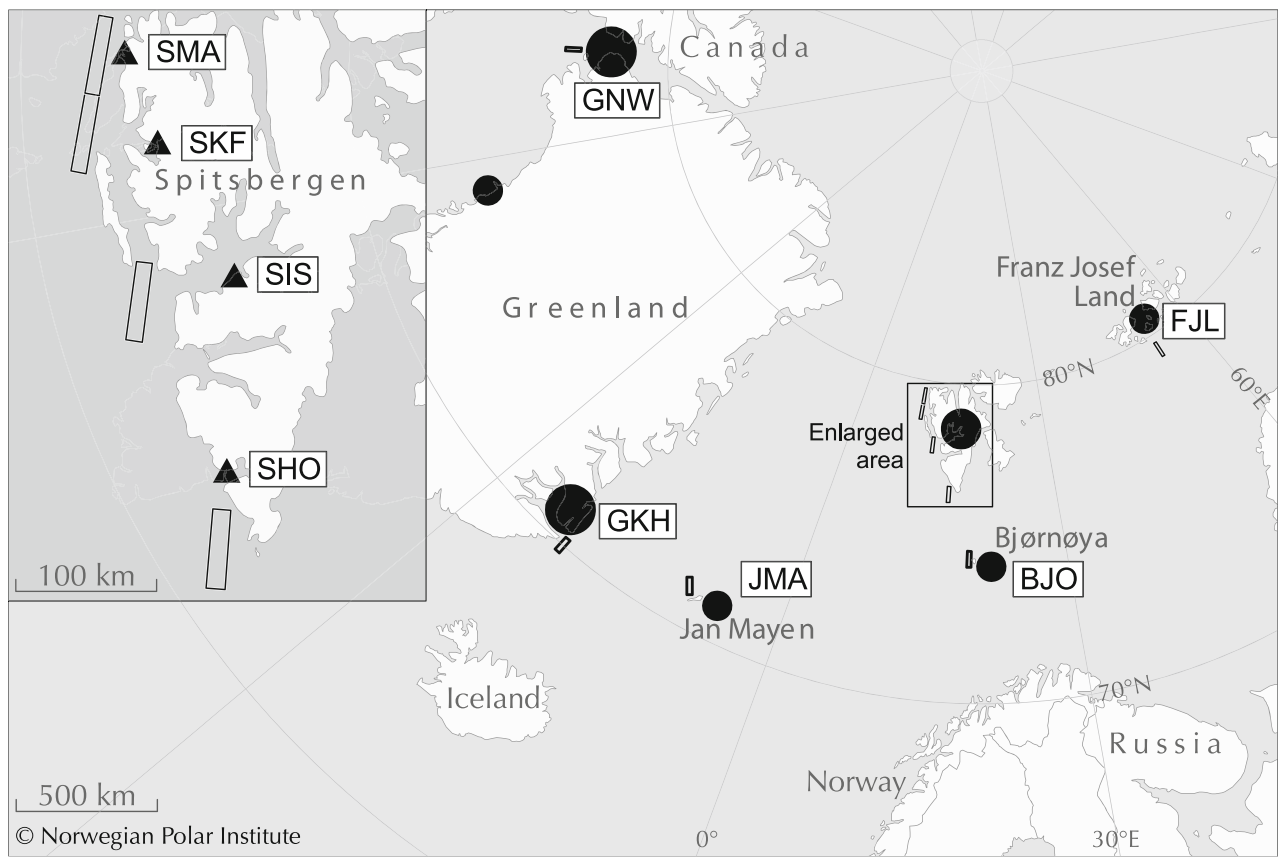


sea surface temperature) and geographical (colony location and distance among populations) parameters that describe the different breeding areas. We expected that ambient temperature along with wind speed (wind chill effect) would impose a thermoregulatory constraint on birds. Thus, according to the heat conservation hypothesis, we predicted that birds breeding in conditions of low air temperature and/or high wind speed would be larger than individuals breeding in areas experiencing milder conditions.

Dovekies have a high rate of energy expenditure which exceeds predictions based on body mass by more than $70 \%$ (Gabrielsen et al. 1991; Konarzewski et al. 1993; Welcker et al. 2009a). To cover their high energy demands, dovekies forage primarily on large, energy-rich zooplankton communities associated with cold, Arctic water masses and avoid warmer, Atlantic waters which contain smaller, less profitable zooplankton species (Karnovsky et al. 2003). According to the starvation resistance hypothesis, we expected that birds from sites where warmer Atlantic waters $\left(\geq 3^{\circ} \mathrm{C}\right)$ dominate would be larger than those with access to more advantageous foraging areas with cold Arctic waters $\left(<3^{\circ} \mathrm{C}\right.$, Loeng 1990) because the former may need to accumulate larger body reserves to accommodate less profitable food resources.

In addition, we evaluated whether morphometric variation was related to geographical distances between breeding sites. Since body size of birds is heritable to a certain extent, we expected a close relationship between similarities in body size and the geographical distance of breeding sites irrespective of environmental conditions if body size variation resulted from distance-dependent gene flow between colonies.

\section{Methods}

Study area and field work

Data were collected during field studies conducted at nine colonies during the breeding season (incubation and chickrearing period, June-August) in 1983, 1991, 1993, and 1997, 2005-2008. The study colonies were located across the breeding range of dovekies and include from west to east: (1) North-west Greenland: Thule District area and Hakluyt Island [further abbreviated as GNW]; (2) East Greenland, Kap Hoegh [GKH]; (3) Jan Mayen [JMA]; (4) Magdalenefjorden [SMA]; (5) Kongsfjorden [SKF]; (6) Isfjorden [SIS]; (7) Hornsund Fjord [SHO]; (8) Bjørnøya [BJO] and (9) Franz Josef Land [FJL] (Fig. 1, coordinates in Table 1).

Most birds were captured at the colony either by mist net, noose carpets spread on the colony area, or by direct capture inside their nest chambers. Some birds (all from GNW, except those from Hakluyt Island and $70 \%$ of those measured in FJL) were shot at sea (for purposes other than the present study), in areas up to $200 \mathrm{~km}$ away from the colony. All caught individuals were ringed, measured, weighed and released without any harm. Shot birds were measured immediately after death, before any postmortem body changes.

Measurements of wing length (maximum flattened cord), head-bill length (from the most distant point of the occipital to the tip of bill), and body mass were taken from each individual. These measurements are routinely taken in many bird species and are considered to be least vulnerable to measurement error. A stopped wing-rule for wing length (with $1 \mathrm{~mm}$ accuracy) and dial calipers for head-bill length

Table 1 Environmental characteristics of the nine breeding colonies of dovekies (mean \pm SD) - air temperature (AT), wind speed (WS), and sea surface temperature (SST)

\begin{tabular}{|c|c|c|c|c|c|c|c|c|}
\hline \multirow[t]{2}{*}{ Colony } & \multicolumn{2}{|c|}{ Coordinates } & \multicolumn{6}{|c|}{ Parameter (mean $\pm \mathrm{SD})$} \\
\hline & & & $\mathrm{AT}\left({ }^{\circ} \mathrm{C}\right)$ & $\begin{array}{l}\text { No of } \\
\text { colony* }\end{array}$ & WS $(\mathrm{km} / \mathrm{h})$ & $\begin{array}{l}\text { No of } \\
\text { colony* }\end{array}$ & $\operatorname{SST}\left({ }^{\circ} \mathrm{C}\right)$ & $\begin{array}{l}\text { No of } \\
\text { colony* }\end{array}$ \\
\hline $\begin{array}{l}\text { (1) NW Greenland, Thule District and } \\
\text { Hakluyt Is. (GNW) }\end{array}$ & $75^{\circ}-78^{\circ} \mathrm{N}$ & $71^{\circ}-78^{\circ} \mathrm{W}$ & $4.8 \pm 1.8$ & 9 & $12.8 \pm 2.8$ & $2-5,8,9$ & $-0.6 \pm 0.9$ & $2-9$ \\
\hline (2) E Greenland, Kap Hoegh (GKH) & $70^{\circ} 43^{\prime} \mathrm{N}$ & $22^{\circ} 38^{\prime} \mathrm{W}$ & $4.8 \pm 1.8$ & 9 & $9.6 \pm 2.6$ & $1-3,6-9$ & $1.1 \pm 1.3$ & $1,3-9$ \\
\hline (3) Jan Mayen (JMA) & $71^{\circ} 00^{\prime} \mathrm{N}$ & $08^{\circ} 30^{\prime} \mathrm{W}$ & $5.2 \pm 1.6$ & 7,9 & $15.6 \pm 4.2$ & $1,2,4,5$ & $4.5 \pm 2.2$ & $1,2,4-6,9$ \\
\hline (4) Svalbard, Magdalenefjorden (SMA) & $79^{\circ} 33^{\prime} \mathrm{N}$ & $10^{\circ} 52^{\prime} \mathrm{E}$ & $4.3 \pm 1.6$ & 6,9 & $9.3 \pm 2.8$ & $1,3-9$ & $2.9 \pm 1.6$ & $1-3,6-9$ \\
\hline (5) Svalbard, Kongsfjorden (SKF) & $79^{\circ} 01^{\prime} \mathrm{N}$ & $12^{\circ} 25^{\prime} \mathrm{E}$ & & & & & $3.3 \pm 1.5$ & $1-3,7-9$ \\
\hline (6) Svalbard, Isfjorden (SIS) & $78^{\circ} 14^{\prime} \mathrm{N}$ & $15^{\circ} 19^{\prime} \mathrm{E}$ & $5.6 \pm 1.7$ & $4,5,7,9$ & $14.7 \pm 2.1$ & $2,4,5,8$ & $3.7 \pm 1.8$ & $1-4,8,9$ \\
\hline (7) Svalbard, Hornsund Fjord (SHO) & $77^{\circ} 00^{\prime} \mathrm{N}$ & $15^{\circ} 33^{\prime} \mathrm{E}$ & $3.8 \pm 1.2$ & $3,6,9$ & $13.6 \pm 3.8$ & $2,4,5,8$ & $4.2 \pm 2.0$ & $1,2,4,5,9$ \\
\hline (8) Svalbard, Bjørnøya (BJO) & $74^{\circ} 22^{\prime} \mathrm{N}$ & $19^{\circ} 01^{\prime} \mathrm{E}$ & $4.7 \pm 1.5$ & 9 & $17.6 \pm 4.1$ & $1,2,4-7$ & $4.8 \pm 1.8$ & $1,2,4-7,9$ \\
\hline (9) Franz Josef Land (FJL) & $80^{\circ}-81^{\circ} \mathrm{N}$ & $49^{\circ}-53^{\circ} \mathrm{E}$ & $-0.1 \pm 0.9$ & $1-8$ & $16.1 \pm 2.8$ & $1,2,4,5$ & $0.2 \pm 0.9$ & $1-8$ \\
\hline
\end{tabular}

The distance between the meteorological stations and the breeding sites varied between 2 and $100 \mathrm{~km}$

* Number of the colony which differs in particular parameter, Tukey HSD tests, $P<0.05$ 
(with $0.1 \mathrm{~mm}$ accuracy) were used, and birds were weighed with a Pesola spring balance (with $2 \mathrm{~g}$ accuracy). All measured birds were adults (fully developed, with uniformly black wing coverts and flight feathers; Stempniewicz 2001).

\section{Environmental data}

Data on sea surface temperature $\left(\mathrm{SST},{ }^{\circ} \mathrm{C}\right)$, with a spatial resolution of $0.5^{\circ}$ (latitude/longitude) from the topmost possible water column (up to $5 \mathrm{~m}$ ), were obtained from the Reyn_Smith OIv2 (Reynolds et al. 2002) database via the IRI/LDEO Climate Data Library (http://iridl.ldeo.columbia. edu/SOURCES/.CARTON-GIESE/.SODA/.v2p0p2-4/.temp ). We selected the $0.5^{\circ}$ box closest to each colony and outside the respective fjords (up to $50 \mathrm{~km}$ from the colony). These areas are likely to represent ocean temperature in the foraging areas of dovekies from the different colonies as earlier studies indicated that dovekies most frequently forage in the vicinity of the breeding colony (within ca $50 \mathrm{~km}$; Karnovsky et al. 2003; Welcker et al. 2009b). Mean SST values for June-August during the last 10 years with available data (1998-2007) were calculated for each study site. The SST values differed significantly among the sites (ANOVA, $F_{8,1071}=182.24, P<0.001$, Table 1 ).

Air temperature and wind speed data were obtained from a database on the website http://www.TuTiempo.net. The meteorological stations closest to each breeding site (distance 2-110 km) were chosen. Comparable data on air temperature and wind speed were available only for the last 13 years (1998-2010) for all colonies except FJL, where data were available for the last 10 years only (1998-2001 and 2005-2010). We took data for the summer months June-August only, the time period when birds regularly attend their breeding sites at all studied colonies. Mean air temperature (AT) and wind speed (WS) for the selected period were calculated for each site. The mean AT and WS values differed significantly among the sites (ANOVA, AT: $\quad F_{7,295}=40.76, \quad P<0.001$, WS: $\quad F_{7,295}=32.33$, $P<0.001$, Table 1). None of the environmental parameters were correlated with each other (Pearson correlations, AT vs WS: $r=-0.22, t_{9}=-0.59, P=0.58$; AT vs. SST: $\quad r=0.43, \quad t_{9}=1.27, \quad P=0.24 ; \quad$ WS vs. SST: $\left.r=0.36, t_{9}=1.03, P=0.34\right)$.

To build a matrix of the shortest possible distances between breeding colonies, we used the measurement tool in Google Earth 5.0. The colonies were separated from each other by distances ranging from $80-2,213 \mathrm{~km}$.

\section{Statistical analyses}

In total, we gathered body measurements from 1,076 adult dovekies, although we did not have the complete set of data for all individuals (sample sizes for particular measurements are given in Fig. 2). To control for intraseasonal change in body mass (Taylor 1994), we only included birds captured during the mid- and late chick-rearing periods.

To examine the relationship between body size and environmental parameters, we used the first principal component (PC1) of a principle component analysis (PCA), reducing the three body measurements (wing length, head-bill length and body mass) to a body size index (BSI). This was done because a combination of parameters is likely to be more adequate as a measure of the overall body size of the birds than a univariate metric (Freeman and Jackson 1990). We only performed the PCA on individuals with a complete set of data. Since the variables entered into the PCA had different units and scales, they were standardized before the analysis was performed. The PC1 extracted from the three variables accounted for $68.8 \%$ of the variability.

Since body size differences between the sexes are negligible (Jakubas and Wojczulanis 2007) and the sex was known only for some individuals, this factor was not taken into account in the data analyses.

In order to test for differences in body size among colonies, we used ANOVA and post hoc Tukey HSD tests with wing length, head-bill length, body mass, and BSI as dependent variables. Furthermore, to test for a change in body size with latitude and longitude, we performed a weighed Pearson correlation (Stanisz 2007). Similarly, to examine the relationship between body size and environmental parameters, the mean BSI for each site was used in weighted Pearson correlation. These analyses were performed in two ways: (1) including both subspecies (all studied breeding sites included) and (2) excluding the $A$. a. polaris subspecies (samples from FJL). This was done in order to assess the effect of a single data point consisting of the considerably larger birds from FJL on our results.

To examine the correlations between differences in body size (BSI) and environmental and geographical distances between colonies, respectively, Mantel tests (with Euclidean similarity measure and 5,000 permutations; Legendre 2000) were performed. The Mantel test evaluates the statistical significance of the correlation between two and more distance matrices, using permutation tests (Telles and Diniz-Filho 2005). The distance matrix of BSI was compared to the matrices of geographical distance and each environmental parameter separately.

Furthermore, a phenogram was constructed from the mean of each of the three body measurements calculated for each of nine study sites to examine the pattern of similarities in the body size of birds among the breeding colonies. Ward's algorithm and Euclidean distance were used in this analysis. 

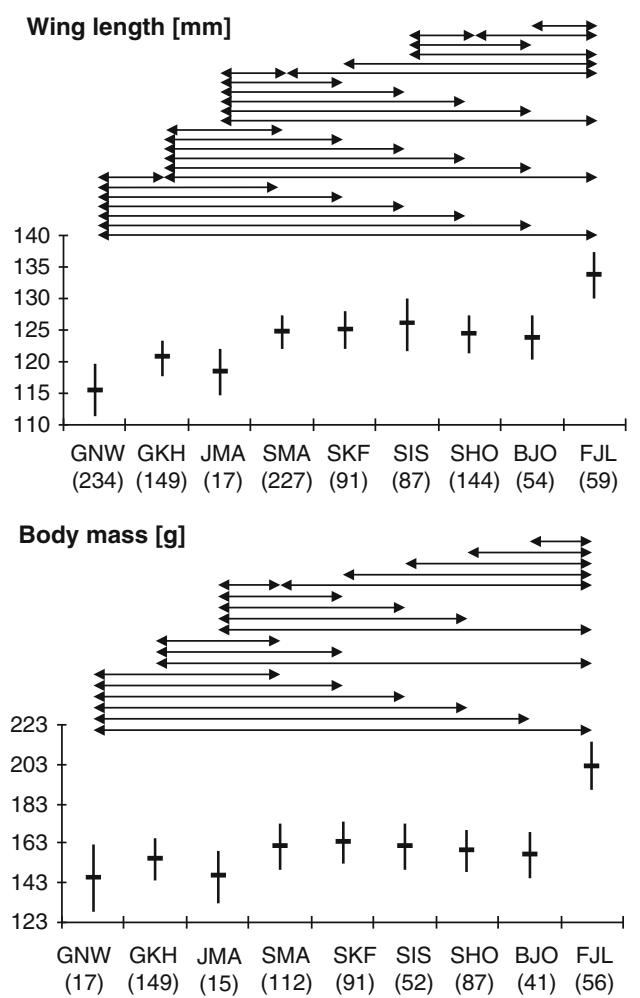

Fig. 2 Body size measurements of dovekies (mean \pm SD) from nine breeding sites (ordered longitudinally). The codes of sites are explained in the body text of "Methods". Sample sizes provided in

Normality of variables was examined by Shapiro-Wilk test. All statistical analyses were performed with the software package STATISTICA 8.0 (StatSoft Inc. 2007), except for the Mantel tests performed in PAST software ver. 1.87 (Hammer et al. 2008).

\section{Results}

Significant differences in all measurements of dovekies' body size were found among the studied breeding sites (ANOVA; wing length: $F_{8,1053}=237.88$; head-bill length: $F_{8,776}=52.77$; body mass: $F_{8,611}=105.66$; BSI: $F_{8,550}=69.17, P<0.001$ in all cases). These differences generally followed a similar pattern (Fig. 2). In all cases, birds from FJL were significantly larger than individuals from Greenland, Svalbard, and Jan Mayen (Tukey HSD tests, $P<0.001$ in all cases; Fig. 2). Significant differences were also found within the nominative subspecies, with birds in Greenland and Jan Mayen being generally smaller than birds in Svalbard (Tukey HSD tests, $P<0.001$; Fig. 2). None of the morphological parameters correlated with latitude (weighted Pearson's correlation; wing length: $r=0.48, t=1.48, n=9, P=0.19$; bill-head length: $r=0.46, t=1.36, n=9, P=0.22$; body mass; $r=0.57$, $t=1.83, n=9, P=0.11)$. However, when measurements
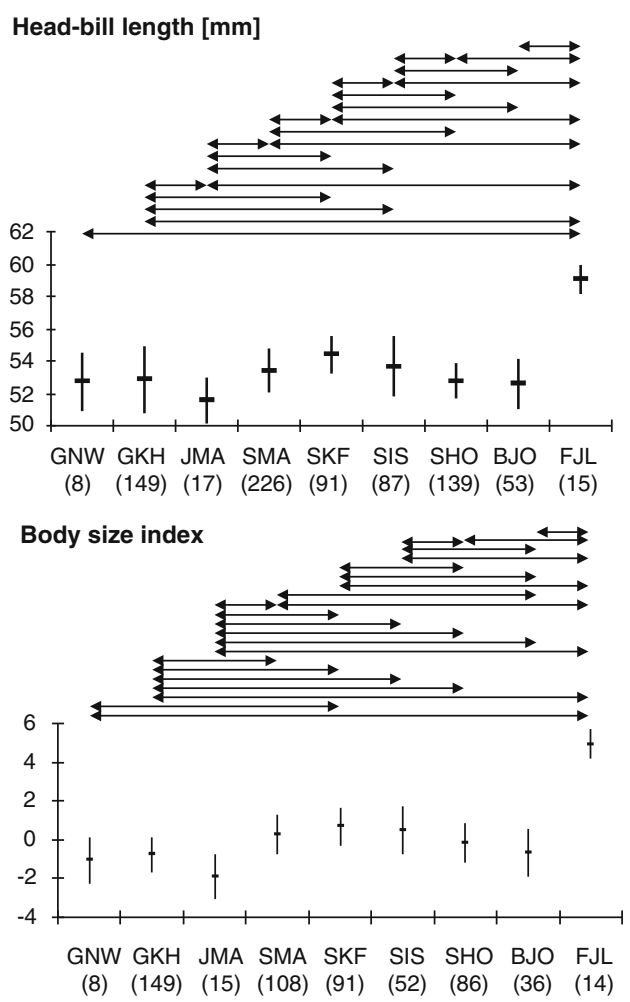

parenthesis are total numbers of birds measured. Significant differences between pairs of colonies (post hoc Tukey HSD tests) are indicated by arrows

were combined in BSI, a significant increase in body size with latitude (south to north) emerged (BSI: $r=0.70$, $t=2.57, n=9, \quad P=0.04)$. In addition, body size parameters and BSI were positively correlated with longitude (wing length: $r=0.96, t=9.25, n=9, P<0.001$; body mass: $r=0.77, t=3.16, n=9, P=0.02$; BSI: $r=0.69, t=2.52, n=9, P=0.04)$, except for head-bill length $(r=0.43, t=1.26, n=9, P=0.25)$, indicating that body size generally increased from west to east (Fig. 2).

Weighted correlation analysis on BSI and environmental features (SST, AT, and WS) performed for both subspecies combined revealed a significant relationship between BSI and air temperature only. The body size of birds increased significantly along with decreasing air temperature (Table 2). However, when the subspecies A. a. alle was considered exclusively, no significant relationship between body size and any of the environmental parameters was found (Table 2). This result was supported by the Mantel tests that indicated that differences in body size correlated significantly with differences in AT only when both subspecies were considered. No correlation was found between differences in body size and differences in SST or WS (Table 2).

Similarly, no significant correlation was found between the geographical distance between colonies and differences 
Table 2 Relationship between dovekie's body size index (mean for each site) and particular environmental parameters (SST-sea surface temperature, AT - air temperature, and WS—wind speed) describing the breeding area

\begin{tabular}{|c|c|c|c|c|c|c|}
\hline & \multirow[t]{2}{*}{ Parameter } & \multicolumn{3}{|c|}{ Pearson's } & \multicolumn{2}{|c|}{ Mantel } \\
\hline & & $r$ & $t$ & $P$ & $r$ & $P$ \\
\hline \multirow[t]{3}{*}{ Both subsp. $(n=9)$} & SST & 0.15 & 0.41 & 0.70 & 0.19 & 0.17 \\
\hline & AT & -0.71 & -2.63 & 0.03 & 0.91 & 0.02 \\
\hline & WS & 0.07 & 0.20 & 0.85 & -0.09 & 0.63 \\
\hline \multirow{3}{*}{$\begin{array}{l}\text { A. a. alle subsp. } \\
\quad(n=8)\end{array}$} & SST & 0.47 & 1.30 & 0.24 & -0.07 & 0.51 \\
\hline & AT & -0.18 & -0.47 & 0.66 & 0.10 & 0.32 \\
\hline & WS & -0.22 & -0.55 & 0.60 & -0.08 & 0.60 \\
\hline
\end{tabular}

The weighted Pearson's correlation analyses and Mantel tests performed for both subspecies and for A. a. alle subspecies separately

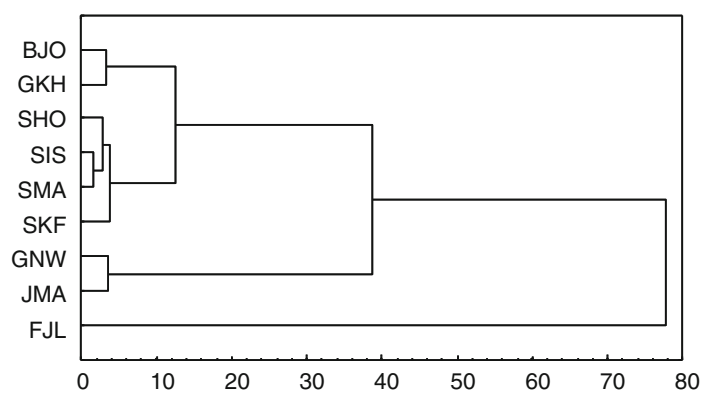

Fig. 3 Phenogram of dovekies' body size similarities constructed from the means of three morphometric measurements (wing length, head-bill length, and body mass) using Ward's algorithm. The codes of breeding sites are explained in the body text of "Methods"

in body size, neither considering both subspecies (Mantel test, $r=0.23, P=0.19$ ) nor considering $A$. a. alle subspecies only $(r=0.31, P=0.14)$.

The phenogram (Fig. 3) indicates similarities in the three body size parameters (wing length, head-bill length, and body mass) between birds from Bjørnøya and $\mathrm{E}$ Greenland, birds from Jan Mayen and NW Greenland, and among birds from the main island of Svalbard (SHO, SIS, SKF, SMA). Birds from FJL were separated as a distinguished cluster (Fig. 3).

\section{Discussion}

In this study, we found substantial variation in the body size of dovekies among nine different colonies spanning a large part of the breeding range of this species. Our data confirm considerable differences in morphometric measurements between the larger subspecies $A$. a. polaris breeding on Franz Josef Land and smaller individuals of the subspecies $A$. $a$. alle breeding in the western part of the breeding range of the dovekie (Stempniewicz et al. 1996). However, we also found significant variation in body size within the nominative subspecies. While some of the differences within $A$. a. alle, for example, a difference in head-bill length between neighboring SKF and SMA, are likely to be the consequence of measurement error inherent in such multi-colony comparisons, a general pattern emerged with birds from Greenland and Jan Mayen being considerably smaller than their conspecifics from Svalbard. This pattern was robust and consistent in all parameters.

In fact, our results suggest a longitudinal increase in the size of dovekies from west to east. A similar pattern of a clinal increase in body size has also been reported in other Atlantic alcids such as thick-billed murre (Uria lomvia; Vaurie 1965), atlantic puffin (Fratercula arctica; Moen 1991), and razorbill (Alca torda; Barrett et al. 1997). While Moen (1991) reported a north-westward increase in body size in the atlantic puffin, the size of thick-billed murres and razorbills seems, similarly to our results in the dovekie, increased from west to east and north-east, respectively (Vaurie 1965; Barrett et al. 1997). Attempts to identify the forces driving the size differentiation have only partly been successful. Although ocean temperature has been evoked as a possible explanation in both atlantic puffin and razorbill, the cause of much of the observed variation remained speculative (Moen 1991; Barrett et al. 1997).

Similarly, we found very little evidence for a correlation between environmental conditions and intra-specific variation in body size in the dovekie. We did not find a negative relationship between body size and SST as predicted by the starvation resistance hypothesis. The lack of such a relationship together with the relatively low range of SST temperatures observed among colonies may indicate that foraging conditions at our study colonies were not diverse enough to result in different starvation avoidance strategies, and/or perhaps flexible foraging behavior is a sufficient mechanism for individuals to adjust to local foraging conditions.

In contrast, we found that body size was negatively correlated with air temperature as predicted by the heat conservation hypothesis. However, given that this relationship disappeared when the birds from FJL were removed from the analysis, the observed pattern may have been only based on one extreme data point. Even though it seems plausible that the large body size of birds from FJL is an adaptation to the severity of the environment (the lowest air temperatures among dovekie breeding sites), the heat conservation hypothesis is unable to explain the variation in body size within the subspecies $A$. a. alle.

It is conceivable that differences in wintering conditions may better explain the observed variation in body size of dovekies. The birds experience extremely harsh weather conditions out at sea during the winter. In fact, the winter 
appears to be a particularly challenging phase of the annual cycle for dovekies, with ambient temperature the main force driving energy expenditure during that time (Fort et al. 2009). Both the heat conservation hypothesis and the starvation resistance hypothesis may therefore apply to winter conditions rather than to conditions birds experience during their relatively short breeding period.

The wintering areas of the particular colonies and the degree to which they overlap, if at all, are largely unknown. Ringing recoveries are scarce and limited to only few breeding sites. However, based on existing recovering data and few pelagic surveys (reviewed in Stempniewicz 2001), it can be assumed that the birds from NW Greenland colony may winter off the coast of Newfoundland and southwest Greenland, while Svalbard birds possibly winter off south-east Greenland. As yet, nothing is known about the wintering grounds of birds from east Greenland and Jan Mayen. There are also no recoveries of birds from Franz Josef Land but large numbers of individuals observed returning to the colony as early as February suggest that those birds may winter relatively close to the archipelago. If wintering areas of the particular subpopulations are like assumed above, an increase in wintering latitude, possibly correlating with a decrease in ambient temperature, may explain body size variation in accordance with the heat conservation hypothesis. However, until more details about particular wintering areas are known (possibly by the use of geolocator technology), their effect on the body size variation of dovekies remains speculative.

Results of the Mantel tests showed that differences in body size were not correlated with differences in the geographical distance between colonies. This was the case both when considering the whole data set and the nominative subspecies $A$. a. alle alone. The phenogram supports the idea that birds from neighboring colonies are not always more similar in body size. While it indicates that birds from colonies on Svalbard are especially similar in size in accordance with the short distances separating these colonies, it also shows a stronger similarity of birds from Bjørnøya with individuals from east Greenland (GKH) than with birds from the Svalbard colonies. This is despite the fact that the distance separating $\mathrm{BJO}$ and $\mathrm{GKH}$ is more than five times larger compared to the closest locations on Svalbard. Similarly, birds from Jan Mayen were more similar to individuals from GNW than to individuals from GKH, despite JMA being almost thousand and a $1 / 2 \mathrm{~km}$ further away from GNW compared to GKH. Whether this pattern can be explained by a stronger gene flow (than expected by geographical distance alone) between these colonies or rather reflects phenotypic plasticity in response to an environmental parameters at breeding areas untested in the present study and/or the conditions in wintering grounds remains to be explored. A molecular study of the genetic diversification of the worldwide population of dovekies is required to estimate the range and degree of gene flow between the breeding colonies.

A complete separate cluster for FJL birds in the phenogram underscores the distinct difference in body size of that population and suggests genetic isolation of the two subspecies. It has been suggested that the morphological disparity between $A$. a. alle and $A$. $a$. polaris has its origin in the separation of a common ancestral population that was split during the ice age and, as a consequence, evolved separately in different glacial refuges. It is conceivable that the larger of the two forms developed in a refugium along the Arctic coast basin while the smaller form was restricted to more southern areas (Bedard 1985). A similar explanation has been proposed to explain the occurrence of large and small individuals in the snow petrel that occur in different proportions (along with intermediates) in different colonies. In this species, body size variability has also been interpreted as the result of genetic modifications due to a separation event rather than phenotypic plasticity alone (Jouventin and Viot 1985; Barbraud and Jouventin 1998).

Although sampling area in the present study covers the largest part of the dovekie breeding range, two other sites would be of great interest to include in a future study, i.e., Novaya Zemlya - a site with the same longitude as FJL and Severnaya Zemlya - a site at the eastern limit of the species' breeding range. These data could help to fully explore the longitudinal and air temperature-dependent increase in the body size of dovekies found in this study and could also help to assess variability in body size within the $A$. $a$. polaris subspecies.

In conclusion, this study provides additional evidence of geographical variation in body size of seabirds breeding at high latitudes. Geographic variability in the body size of dovekies is distinctive with a north-eastward increase. The forces driving this pattern remain speculative; the environmental factors (air temperature, wind speed, and sea surface temperature) tested at breeding areas are unlikely to be important predictors of size in this species. More data are needed, including those from the easternmost breeding colonies for which data are not available to date, to determine the contribution of phenotypic plasticity and genetic control to the observed spatial differences.

Acknowledgments We thank Dr David Boertmann for morphometric data from NW Greenland and his thoughtful comments on earlier versions of this manuscript. Thanks also go to the many fieldworkers across the whole study area, J.A. van Franeker for the organization of the Jan Mayen expedition in 1983, the commander and crew of Forsvarets Stasjon Jan Mayen for logistic support and to A. Skoglund for preparing Fig. 1. The project benefited from grants from Polish Ministry of Science and Higher Education (IPY/25/2007), Norway through the Norwegian Financial Mechanism (ALKEKONGE, PNRF234-AI-1/07), University of Gdańsk (BW1440-5-0393-8), Greenland Institute of Natural Resources, the French Polar Institute Paul-Emile 
Victor (Grant 388 to David Grémillet), National Science Foundation (grant 0612504 to NJK and AH, 0301469 to NJK and Office of Polar Programs grant 9725071 to G.L. Hunt, Jr.). All field work was conducted under the permission of the Governor of Svalbard and the Greenland Home Rule, Ministry of Environment and Nature and the Hunters-Trappers Organization of Qaanaaq, Greenland.

Open Access This article is distributed under the terms of the Creative Commons Attribution Noncommercial License which permits any noncommercial use, distribution, and reproduction in any medium, provided the original author(s) and source are credited.

\section{References}

Ainley DG (1980) Geographic variation in Leach's Storm-petrel. Auk 97:837-853

Ashton KG (2002) Patterns of within-species body size variation of birds: strong evidence for Bergmann's rule. Global Ecol Biogeogr 11:505-523

Barbraud C, Jouventin P (1998) What causes body size variation in the Snow Petrel Pagodroma nivea? J Avian Biol 29:161-171

Barrett RT, Anker-Nielsen T, Krasov YV (1997) Can Norwegian and Russian Razorbills Alca torda be identified by their measurements? Mar Ornithol 25:5-8

Bedard J (1985) Evolution and characteristic of the Atlantic Alcidae. In: Nettleship DN, Birkhead TR (eds) The Atlantic Alcidae. The evolution, distribution and biology of the Auks inhabiting the Atlantic Oceans and adjacent water areas. Academic Press, New York, pp 427-488

Bergmann C (1847) Uber die verhaltnisse der warnoekonomie der thiere zu ihrer grosse. Gottinger Studien 1:595-708

Blackburn TM, Gaston KJ, Loder N (1999) Geographic gradients in body size; a clarification of Bergmann's rule. Divers Distrib 5:165-174

Boertmann D, Mosbech A (1998) Distribution of Little Auk (Alle alle) breeding colonies in Thule District, Northwest Greenland. Polar Biol 19:206-210

Calder WA (1974) Consequences of body size for avian energetics. In: Paynter RA Jr (ed) Avian energetics. Nuttal Ornithological Club, Cambridge, MA, pp 86-151

Camphuysen CJ (1989) Biometrics of auks at Jan Mayen. Seabird $12: 7-10$

Cramp S (ed) (1985) Handbook of the birds of Europe, the Middle East, and North Africa, Vol. IV: Terns to Woodpeckers. Oxford University Press, New York

Egevang C, Boertmann D, Mosbech A, Tamstorf MP (2003) Estimating colony area and population size of Little Auks Alle alle, at Northumberland Island using aerial images. Polar Biol 26:8-13

Fort J, Porter WP, Grémillet D (2009) Thermodynamic modeling predicts energetic bottleneck for seabirds wintering in the northwest Atlantic. J Exp Biol 212:2483-2490

Freeman S, Jackson WM (1990) Univariate metrics are not adequate to measure avian body size. Auk 107:69-74

Gabrielsen GW, Taylor JRE, Konarzewski M, Mehlum F (1991) Field and laboratory metabolism and thermoregulation in Dovekies (Alle alle). Auk 108:71-78

Hammer Ø, Harper DAT, Ryan RD (2008) PAST_PAlaeontological STatistics, ver. 1.87, http://folk.uio.no/ohammer/past

Isaken K, Bakken V (1996) Migration routes and wintering area of Little Auks Alle alle ringed in Svalbard. Sula 10:229-238

Isaksen K, Gavrilo M (2000) Little auk Alle alle. In: Anker-Nilssen T, Bakken V, Strøm H, Golovkin AN, Bianki VV, Tatarinkova IP (eds)
The status of marine birds breeding in the Barents Sea Region. Tromso: Norsk Polarinstitutt, Rapportserie 113, pp 131-136

Jakubas D, Wojczulanis K (2007) Predicting the sex of Dovekies by discriminate analysis. Waterbirds 30:92-96

James FC (1970) Geographic size variation in birds and its relationship to climate. Ecology 51:365-390

Jouventin P, Viot CR (1985) Morphological and genetic variability of Snow Petrels Pagodroma nivea. Ibis 127:430-441

Kampp K, Meltofte H, Mortensen CE (1987) Population size of the Little Auk Alle alle in East Greenland. Dan Ornithol Foren Tidsskr 81:129-136

Karnovsky NJ, Kwaśniewski S, Węsławski JM, Walkusz W, Beszczyńska-Moller A (2003) Foraging behaviour of Little Auks in a heterogeneous environment. Mar Ecol Prog Ser 253:289-303

Konarzewski M, Taylor JRE, Gabrielsen GW (1993) Chick energy requirements and adult energy expenditures of Dovekies (Alle alle). Auk 110:343-353

Legendre P (2000) Comparison of permutation methods for the partial correlation and partial Mantel tests. J Stat Comput Sim 67:37-73

Loeng H (1990) Features of the physical oceanographic conditions of the Barents Sea. Polar Res 10:5-15

Mehlum F, Bakken V (1994) Seabirds in Svalbard (Norway): status, recent changes and management. In: Nettleship DN, Burger J, Gochweld M (eds) Seabirds on Islands: threats, case studies and action plans. Birdlife conservation series No. 1. Birdlife International, Cambridge, UK, pp 155-171

Moen SM (1991) Morphologic and genetic variation among breeding colonies of the Atlantic Puffin (Fratercula arctica). Auk 108:755-763

Monaghan P, Coulson JC, Duncan N, Furness RW, Shedden CB, Thomas C (1983) The geographical variation of the Herring Gull Larus argentatus within Britain and in northern Europe; a biometrical approach. Ibis 125:412-417

Reynolds RW, Rayner RA, Smith TM, Stokes DC, Wang WQ (2002) An improved in situ and satellite SST analysis for climate. J Clim 15:1609-1625

Roby DD, Brink KL, Nettleship DN (1981) Measurements, chick meals and breeding distribution of Dovekies (Alle alle) in northwest Greenland. Arctic 34:241-248

Stanisz A (2007) Przystępny kurs statystyki z zastosowaniem STATISTICA PL na przykładach z medycyny, in Polish. (Accessible statistics course with STATISTICA PL application with examples from medicine). Statsoft, Kraków, Poland

Stempniewicz L (2001) Alle alle. Little Auk. The Journal of the Birds of the Western Palearctic. Oxford University Press. BWP Update 3:175-201

Stempniewicz L, Skakuj M, Iliszko L (1996) The Little Auk Alle alle polaris of Franz Josef Land: a comparison with Svalbard Alle a. alle populations. Polar Res 15:1-10

Stenhouse JH (1930) The Little Auk (Alle alle polaris Sub-Sp. Nov.) of Franz Jozef Land. Scot Nat 182:47-49

Taylor JRE (1994) Changes in body mass and body reserves of breeding Little Auks (Alle alle L.). Polish Polar Res 123:149-168

Telles MPC, Diniz-Filho JAF (2005) Multiple Mantle tests and isolation-by-distance, taking into account long-term historical divergence. Genet Mol Res 4:742-748

Vaurie C (1965) The birds of the Palearctic fauna: non-Passeriformes. Witherby, London, UK

Welcker J, Harding AMA, Kitaysky AS, Speakman JR, Gabrielsen GW (2009a) Daily energy expenditure increases in response to low nutritional stress in an Arctic-breeding seabird with no effect on mortality. Funct Ecol 23:1081-1090

Welcker J, Harding AMA, Karnovsky NJ, Steen H, Strøm H, Gabrielsen GW (2009b) Flexibility in the bimodal foraging strategy of a high Arctic alcid, the Little Auk Alle alle. J Avian Biol 40:388-399 